\title{
Isabelle Handy, Musiciens au temps des derniers Valois
} (1547-1589)

\section{Michele Mastroianni}

\section{(2) OpenEdition \\ 1 Journals}

\section{Edizione digitale}

URL: http://journals.openedition.org/studifrancesi/7880

DOI: 10.4000/studifrancesi.7880

ISSN: 2421-5856

\section{Editore}

Rosenberg \& Sellier

\section{Edizione cartacea}

Data di pubblicazione: 1 juillet 2009

Paginazione: 382

ISSN: 0039-2944

\section{Notizia bibliografica digitale}

Michele Mastroianni, «Isabelle Handy, Musiciens au temps des derniers Valois (1547-1589)», Studi

Francesi [Online], 158 (LIII | II) | 2009, online dal 30 novembre 2015, consultato il 08 janvier 2021. URL: http://journals.openedition.org/studifrancesi/7880 ; DOI: https://doi.org/10.4000/studifrancesi.7880

Questo documento è stato generato automaticamente il 8 janvier 2021.

\section{c)}

Studi Francesi è distribuita con Licenza Creative Commons Attribuzione - Non commerciale - Non opere derivate 4.0 Internazionale. 


\section{Isabelle Handy, Musiciens au temps des derniers Valois (1547-1589)}

Michele Mastroianni 


\section{NOTIZIA}

ISABELLE HANDY, Musiciens au temps des derniers Valois (1547-1589), Paris, Champion, 2008

(«Bibliothèque Littéraire de la Renaissance», LXIII), pp. 697.

La ricca e interessante thèse di I. Handy non è soltanto una storia della musica francese rinascimentale - musica sicuramente oggi alla moda e celebrata come espressione del grande rifiorire umanistico europeo, ma ancora poco conosciuta filologicamente e in attesa di ulteriori scavi d'archivio -, ma è una storia di più ampio respiro che tende a situare quest'arte «nel suo quotidiano, contribuendo a una migliore conoscenza del mestiere del musicista e proponendo una riflessione sul ruolo della musica a corte». Il periodo studiato è quello che va dal regno di Henri II a quello di Henri III, periodo tormentatissimo, ma anche periodo del massimo espandersi della civiltà, della letteratura e delle arti rinascimentali, che trovano nell'organizzazione della vita di corte un punto costante di riferimento. Attraverso un paziente spoglio degli archivi nazionali l'A. ha raccolto una documentazione volta a mettere in luce i musicisti - una vera folla di nomi in parte ignoti - nell'esercizio delle loro funzioni, evidenziando lo svolgimento delle carriere di questi artisti, le modalità con cui sono reclutati, il modo in cui vivono, evidenziando anche, sul piano più propriamente musicale, le novità e le innovazioni culturali. La prima parte del volume è consacrata allo studio del 'mestiere' del musicista, la seconda analizza il funzionamento delle istituzioni musicali della corte, la terza si interroga sul ruolo e sullo statuto sociale dei musicisti nel periodo preso in considerazione. Una quarta parte, utilissima agli studiosi e densissima (pp. 369-615), offre, in quadri sinottici, un repertorio dei musicisti e un'ampia raccolta di documenti d'archivio. Concludono il libro un glossario e una ricca bibliografia. 